\title{
UPAYA MENINGKATKAN PEMAHAMAN KONSEP MAHASISWA DENGAN MENGGUNAKAN MODEL PROBLEM BASED INSTRUCTION PADA MATA KULIAH ANALISA VEKTOR UNIVERSITAS GRAHA NUSANTARA PADANGSIDIMPUAN
}

\author{
Lilis Harianti Hasibuan, Susi Sulastri Lubis \\ Pendidikan Matematika, FKIP Universitas Graha Nusantara Padangsidimpuan \\ lilishsb@gmail.com
}

DOI : 10.31604/ptk.v1i3.147-159

\begin{abstract}
This research type is Classroom Action Research with a student population of sixth semester Graha Nusantara University which amounted to 26 people with the object model of learning using problem-based instruction as an effort to improve concept understanding student study on vector analysis course. The results showed the results of concept comprehension cycle I test with problem-based instruction obtained of $69.23 \%$ sufficient criteria and on the second cycle obtained of $84.62 \%$ good criteria. Based on the observation of student activity on the first cycle obtained student activity levels of $70.56 \%$ with sufficient category and on the second cycle increased student activity to $86.68 \%$ with the good category. As for the observation of lecturer ability of cycle I obtained the average value 3,428571 with the category of "Good" and cycle II increased to 4.107143 with the category of "Good." The conclusion of this study is the use of problem-based instruction learning models can improve students' understanding of concepts in vector analysis subjects.
\end{abstract}

Keywords: Concept Understanding, Problem Based Instruction, Analysis Vector.

\begin{abstract}
Abstrak
Jenis penelitian ini adalah Penelitian Tindakan Kelas dengan populasi mahasiswa semester VI Universitas Graha Nusantara Padangsidimpuan yang berjumlah 26 orang dengan objek model pembelajaran menggunakan problem based instruction sebagai upaya meningkatkan pemahaman konsep belajar mahasiswa pada mata kuliah analisa vektor di Universitas Graha Nusantara. Hasil penelitian menunjukkan hasil tes pemahaman konsep siklus I dengan problem based instruction diperoleh persentase sebesar 69,23\% kriteria cukup dan pada silkus II diperoleh persentase sebesar $84,62 \%$ kriteria baik. Berdasarkan hasil observasi aktivitas mahasiswa pada siklus I diperoleh kadar aktivitas mahasiswa 70,56\% dengan kategori cukup dan pada siklus II terjadi peningkatan aktivitas mahasiswa menjadi 86,68\% dengan kategori baik. Sedangkan untuk hasil observasi kemampuan dosen siklus I diperoleh nilai rata - rata 3,428571 dengan kategori "Baik" dan siklus II meningkat menjadi 4,107143 dengan kategori "Baik". Kesimpulan penelitian ini adalah Penggunaan model pembelajaran problem based instruction dapat meningkatkan pemahaman konsep mahasiswa pada mata kuliah analisa vektor.
\end{abstract}

Kata Kunci: Pemahaman Konsep, Problem Based Instruction, Analisis Vector.

PeTeKa (Jurnal Penelitian Tindakan Kelas dan Pengembangan Pembelajaran) | 147 
PeTeKa (Jurnal Penelitian Tindakan Kelas dan Pengembangan Pembelajaran)

Vol 1 No 3 Tahun 2018 Hal 147-159

\section{PENDAHULUAN}

Salah satu masalah yang dihadapi dunia pendidikan kita adalah masalah lemahnya proses pembelajaran. Dalam proses pembelajaran, anak kurang didorong untuk mengembangkan kemampuan berfikir. Proses pembelajaran di dalam kelas diarahkan kepada kemampuan anak untuk menghafal informasi tanpa dituntut untuk memahami informasi yang diingatnya itu untuk menghubungkannya ke kehidupan sehari-hari. Akibatnya, ketika anak lulus sekolah, mereka hanya pintar secara teori, tetapi mereka miskin aplikasi. Banyak hal yang menyebabkan rendahnya pemahaman konsep mahasiswa, salah satunya adalah model pembelajaran yang digunakan di kampus masih cenderung berpusat kepada dosen, dan kurang menarik perhatian mahasiswa untuk belajar karena kurangnya laboratorim, dan media pembelajaran. Model pembelajaran yang dapat membuat mahamahasiswa menjadi aktif untuk berfikir salah satunya adalah Problem Based Learning (Pembelajaran Berdasarkan Masalah). Menurut Yeung (dalam Bilgin, 2009) PBL adalah suatu cara yang mendorong pemahaman lebih dalam dari suatu materi, bukan pemahaman yang dangkal, dan merupakan pembelajaran yang berorientasi pada masalah sehingga para mahasiswa tidak hanya memperoleh pengetahuan dasar selama belajar, tetapi memperoleh pengalaman bagaimana menggunakan pengetahuannya untuk menyelesaikan permasalahan yang sebenarnya.

Berdasarkan permasalahan

diatas, maka perlu dicari solusi sehingga oleh peneliti dipandang perlu melakukan suatu penelitian tindakan kelas yaitu menerapkan pembelajaran berbasis masalah (Problem Based Instruction).
Model pembelajaran problem based instruction adalah suatu model pembelajaran yang mendorong pemahaman lebih di dalam pembelajaran, guna meningkatkan pemahaman mahamahasiswa tentang konsep, melibatkan mahasiswa secara aktif dalam pembelajaran dan mendorong pembelajaran mandiri yang berpusat pada mahasiswa.

Dalam struktur matematika banyak dijumpai konsep-konsep. Setiap konsep tidak berdiri sendiri melainkan berhubungan dengan konsep lain. Semua konsep secara bersama-sama membentuk suatu jaringan pengetahuan dalam bentuk siswa. Pemahaman konsep terdiri dari 2 kata yaitu pemahaman dan konsep. Proses pemahaman terjadi karena adanya kemampuan menghubungkan suatu materi baru dengan materi sebelumnya yang telah terjadi. Pemahaman berasal dari kata dasar 'paham' yang berarti mengerti benar. Arends (2008) mengemukakan bahwa "konsep adalah gambaran dari suatu hal yang didasarkan pada sifat yang dimilikinya”. Konsep adalah suatu ide abstrak yang membantu seseorang dalam mengelompokkan objek-objek atau kejadian-kejadian tersebut termasuk contoh atau non contoh dari ide abstrak tersebut. Pemahaman konsep merupakan bagian yang sangat penting dalam proses pembelajaran matematika. Hal ini didukung oleh Hyde (dalam Arends, 2008) yang menyatakan bahwa "tujuan utama dari pembelajaran matematika adalah pemahaman konsep sehingga siswa tidak hanya sekadar mengetahui atau mengingat suatu konsep matematika".

Menurut Gagne (Suherman, dkk., 2001) konsep adalah ide abstrak yang memungkinkan kita dapat mengelompokkan objek ke dalam contoh dan non contoh. Sedangkan Suherman (2003) menyatakan bahwa 
konsep adalah kumpulan fakta spesifik yang saling terkait secara fungsional. Maka konsep adalah suatu abstraksi yang mewakili satu kelas objek-objek, kejadian-kejadian, kegiatan-kegiatan, atau hubungan yang mempunyai atribut yang sama.

Pemahaman konsep dapat membantu siswa untuk mengingat. Hal tersebut dikarenakan ide-ide matematika yang siswa peroleh dengan memahami saling berkaitan, sehingga siswa lebih mudah untuk mengingat dan menggunakan, serta menyusunnya kembali saat lupa. Siswa mengingat kembali apa yang mereka ingat dan mencoba menggambarkan dengan menggunakan pemikiran sendiri. Pemahaman merupakan aspek yang sangat penting dalam pembelajaran matematika, karena dengan memahami konsep, siswa dapat mengembangkan kemampuannya dalam pembelajaran matematika, siswa dapat menerapkan konsep yang telah dipelajarinya untuk menyelesaikan permasalahan sederhana sampai dengan yang kompleks. Mata pelajaran matematika disekolah diberikan mulai dari konsep yang sederhana ke konsep yang lebih kompeks.

Problem Based Instruction (PBI) pertama kali dikembangkan sebagai suatu model pembelajaran pada tahun 1970 di sekolah medis McMaster Kanada (Kolmos, 2003). Terdapat beberapa pengertian model pembelajaran PBI atau pembelajaran berbasis masalah seperti berikut.

a. Pembelajaran berbasis masalah merupakan suatu model

pembelajaran yang didasarkan pada banyaknya permasalahan yang membutuhkan penyelidikan autentik yakni, penyelidikan yang membutuhkan penyelesaian nyata dari permasalahan yang nyata (Trianto, 2007). b. Menurut Tan (dalam Rusman, 2010), pembelajaran berbasis masalah merupakan penggunaan berbagai macam kecerdasan yang melakukan konfrontasi terhadap tantangan dunia nyata, kemampuan untuk menghadapi segala sesuatu yang baru, dan kompleksitas yang ada.

Dari beberapa pengertian tersebut dapat diambil kesimpulan bahwa model pembelajaran berbasis masalah merupakan model pembelajaran yang didasarkan pada suatu masalah, masalah ini akan mendorong siswa untuk memahami suatu materi pembelajaran melalui rangkaian aktivitas belajar yang harus dilaluinya dengan menggunakan berbagai potensi yang dimiliki. Margetson (dalam Rusman, 2010) mengemukakan pembelajaran berbasis masalah membantu untuk meningkatkan perkembangan keterampilan belajar sepanjang hayat dalam pola pikir yang terbuka, reflektif, kritis, dan belajar aktif. PBL menggeser kebiasaan faculty-centered menjadi studentcentered (Kolmos, 2003).

\section{METODE}

Penelitian ini dilaksanakan di FKIP UGN Padangsidimpuan yang beralamat di Bukit Tor Simarsayang. Waktu penelitian ini dilaksanakan sesuai pada mata kuliah yang akan di tes yaitu Statistik Matematika. Materi ini dibahas pada semester Genap selama lima bulan dan penelitian ini dilaksanakan pada tanggal 06 juni-06 agustus 2018

Jenis penelitian ini adalah Penelitian Tindakan Kelas (PTK). Tindakan yang diberikan adalah penerapan problem based instruction. Populasi dalam penelitian ini adalah mahasiswa semester VI Program Studi Pendidikan Matematika FKIP UGN Padangsidimpuan yang berjumlah 26 
PeTeKa (Jurnal Penelitian Tindakan Kelas dan Pengembangan Pembelajaran)

Vol 1 No 3 Tahun 2018 Hal 147-159

orang yang terdiri dari 6 mahasiswa lakilaki dan 20 mahasiswa perempuan. Seluruh populasi dijadikan sampel dalam penelitian ini.

Objek penelitian ini adalah pelaksanaan pembelajaran matematika dengan model pembelajaran PBI sebagai upaya untuk meningkatkan pemahaman konsep belajar pada mata kuliah analisa Vektor Program Studi Pendidikan Matematika FKIP UGN Padangsidimpuan.

\section{Tahap Perencanaan}

Kegiatan yang dilakukan pada tahap ini adalah menyusun perangkat pembelajaran seperti: Rencana Pembelajaran (RPP) yaitu dengan pembelajaran menggunakan model pembelajaran based instruction. Menyusun bahan ajar/modul untuk mata kuliah analisa vektor. Modul yang dikembangkan adalah modul yang memuat materi mata kuliah analisa vektor berisi tentang vektor konstant, fungsi vektor, diferensial vektor, dan integral vektor.

\section{Tahap Pelaksanaan}

Kegiatan-kegiatan yang dilakukan pada tahap ini adalah melakukan pembelajaran matematika dengan model pembelajaran problem based insstruction untuk meningkatkan pemahaman konsep mahasiswa.

\section{Tahap Observasi}

Observasi yang dilakukan

merupakan pengamatan terhadap keseluruhan aktivitas dan perubahan yang terjadi pada saat diberikan tindakan. Didalam penelitian ini dilakukan pengamatan terhadap pemahaman konsep mahasiswa, Tutor dan Dosen dalam proses belajar mengajar.

\section{Tahap Refleksi}

Kegiatan yang dilakukan pada tahap ini adalah:

a. Menganalisis dan memberikan arti terhadap data yang diperoleh, memperperjelas data, sehingga diambil kesimpulan dari tindakan yang telah dilakukan.

b. Hal yang dilakukan pada repleksi adalah mengulas balik tentang perangkat pembelajaran, dan pemahaman konsep Mahasiswa dalam pembelajaran.

c. Hasil refleksi ini kemudian digunakan sebagai dasar siklus berikutnya.

d. Merancang tindakan yang diperlukan untuk siklus selanjutnya.

Hasil repleksi pada siklus I dapat ditindak lanjuti pada siklus II, dan bagian seterusnya. Peneliti akan berhenti bila memenuhi syarat dengan kriteria berikut:

a. Terdapat $85 \%$ dari jumlah mahasiswa yang mengikuti tes memiliki pemahaman konsep belajar analisa vektor minimal cukup.

b. Apabila tingkat kemampuan Dosen / Peneliti dalam mengelola pembelajaran untuk tiap pertemuan untuk tiap pertemuan mencapai kriteria minimal sedang.

c. Meningkatnya pemahaman konsep mahasiswa di dalam kelas yang disesuaikan dengan model dari lembar observasi telah mencapai $85 \%$.

Terdapat minimal $85 \%$ mahasiswa yang mengikuti pembelajaran memberi respon yang positif terhadap komponen kegiatan pembelajaran.

\section{HASIL DAN PEMBAHASAN}

Pemaparan hasil penelitian disajikan berdasarkan pelaksanaan 
siklus. Hasil penelitian setiap siklus dipaparkan sebagai berikut.

\section{Perencanaan}

Pada tahap ini beberapa hal yang dilakukan adalah sebagai berikut:

a. Mengkaji silabus untuk mata kuliah analisa vektor

b. Membuat modul sebagai bahan ajar untuk mata kuliah analisa vektor

c. Menyiapka RPP untuk proses pembelajaran, lembar observasi, dan catatan lapangan

d. Menyiapkan instrument tes analisa vektor

e. Menyiapkan infokus, spidol, dan yang dianggap perlu

f. Mengkoordinasikan tindakan dengan rekan sejawat sebagai observer

Sebelum dilaksanakan tindakan pada siklus I, peneliti dan rekan sejawat atau tim peneliti melaksanakan pra tindakan pada tanggal 16 juli 2018 . Kegiatan pada pra tindakan adalah membentuk kelompok belajar yang beranggotakan 3 orang mahasiswa dengan pemberian masalah yang dekat dengan kehidupan sehari-hari.

\section{Tindakan}

Siklus I merupakan pembelajaran dengan pokok bahasan Vektor dan skalar. Strategi Pembelajaran Problem Based Instruction (PBI) mulai di perkenalkan pada mahasiswa dalam pembelajaran ini. Diakhir pembelajaran siklus I berlangsung, pada pertemuan ke 4 dilaksanakan tes pemahaman konsep mahasiswa, maka hasil yang di dapat dari tes tersebut dapat dilihat pada tabel 1.

\section{Pengamatan}

Peneliti dan observer

melaksanakan pengamatan terhadap proses pelaksanaan tindakan selama berlangsungnya siklus I. Pengamatan dibatasi pada pemahan konsep mata kuliah analisa vektor. selama proses tindakan peneliti, rekan sejawat, dan observer mengamati reaksi kelompok yang timbul ketika proses kegiatan belajar berlangsung. Pelaksanaan pembelajaran dilakukan sesuai tahapan pembelajaran problem based instruction.

Pembelajaran pada saat tindakan sangat berbeda dibanding pembelajaran sebelum tindakan kelas dilakukan. pada saat awal pembelajaran mahsiswa diseri tugas untuk mendefinisikan pengertian dari vektor dan bagaimana aplikasinya dalam kehidupan sehari-hari. mahasiswa harus dapat nenemukan masalah dalam dunia mereka yang akan diselesaikan dengan aljabar vektor.

Kemudian mahasiswa yang sudah dibagi ke dalam beberapa kelompok memberikan satu atau lebih contoh-contoh objek yang mereka amati. setelah mahasiswa menemukan contoh objeknya, mereka harus menyebutkan alas an mereka memilih objek tersebut atau kajian tersebut untuk dimodelkan atau dianalisis secara vektor atau deferensiasi vektor.

Kemudian membahas ciri-ciri atau karakteristik dari kajian tersebut untuk di modelkan menjadi analisis vektor. Pelaksanaan pembelajaran di kelas perkuliahan diupayakan mengikuti langkah-langkah pembelajaran problem based instruction.

\section{Evaluasi Hasil}

Pengamatan atau observasi merupakan bagian proses dari pengumpulan data yang diperlukan dalam penelitian. Dosen yang bertindak sebagai kolabolator mengamati mahasiswa yang sedang mengikuti proses belajar di kelas dengan pokok bahasan Bangun analisis vektor. Pelaksanaan dilakukan pada saat mahasiswa mengikuti proses pembelajaran dengan model pembelajaran problem based instruction 
PeTeKa (Jurnal Penelitian Tindakan Kelas dan Pengembangan Pembelajaran)

Vol 1 No 3 Tahun 2018 Hal 147-159

untuk meningkatkan pemahaman konsep matematika mahasiswa. Observer memiliki peran mengamati dan memotret semua aktivitas mahasiswa yang terjadi di kelas ketika tindakan dilakukan.
Adapun hasil pengamatan observer terhadap aktivitas mahasiswa dalam pembelajaran dilaksanakan setiap kali pertemuan dimana pada siklus I diadakan 4 kali pertemuan dapat dilihat pada tabel 2 .

Tabel 1: Deskripsi Nilai Hasil Tes Pemahaman Konsep analisa vektor siklus I

\begin{tabular}{ccccc}
\hline No & Nilai & $\begin{array}{c}\text { Jumlah Siswa } \\
\text { (Orang) }\end{array}$ & Persentase & Kategori \\
\hline 1 & $90-100$ & 3 & $11,54 \%$ & Sangat Baik \\
2 & $80-89$ & 2 & $18,18 \%$ & Baik \\
3 & $65-79$ & 11 & $42.31 \%$ & Cukup \\
4 & $55-64$ & 6 & $23,07 \%$ & Kurang \\
5 & $0-54$ & 4 & $15,38 \%$ & Sangat Kurang \\
& Total & $\mathbf{2 6}$ & $\mathbf{1 0 0 \%}$ & \\
\hline
\end{tabular}

Tabel 2: Hasil Observasi Siklus 1 Terhadap Kegiatan dosen dan mahasiswa

\begin{tabular}{|c|c|c|}
\hline INDIKATOR & SKOR & $\begin{array}{l}\text { PERSENTASE } \\
\text { SKOR } \\
\end{array}$ \\
\hline $\begin{array}{l}\text { 1. Kemampuan memotivasi siswa/mengkomunikasikan tujuan } \\
\text { pembelajaran }\end{array}$ & 26 & $86,67 \%$ \\
\hline $\begin{array}{l}\text { 2. Kemampuan menghubungkan pelajaran saat itu dengan } \\
\text { pelajaran sebelumnya atau membahas PR }\end{array}$ & 20 & $66,67 \%$ \\
\hline 3. Kemampuan menjawab soal & 22 & $73,33 \%$ \\
\hline $\begin{array}{l}\text { 4. Kemampuan mengarahkan siswa untuk menemukan jawaban } \\
\text { dan cara menjawab soal, dengan memberikan bantuan terbatas }\end{array}$ & 20 & $66,67 \%$ \\
\hline 5. Kemampuan mengoptimalkan interaksi siswa dalam bekerja & 23 & $76,67 \%$ \\
\hline $\begin{array}{l}\text { 6. Kemampuan mendorong siswa untuk membandingkan } \\
\text { jawaban dengan jawaban temannya }\end{array}$ & 23 & $76,67 \%$ \\
\hline 7. Kemampuan memimpin diskusi kelas/ menguasai kelas & 26 & $86,67 \%$ \\
\hline $\begin{array}{l}\text { 8. Kemampuan mengarahkan siswa untuk menemukan sendiri } \\
\text { dan menarik kesimpulan tentang } \\
\text { konsep/prinsip/definisi/teorema/rumus/prosedur matematika }\end{array}$ & 20 & $66,67 \%$ \\
\hline $\begin{array}{l}\text { 9. Kemampuan mendorong siswa untuk mau bertanya, } \\
\text { mengeluarkan pendapat atau menjawab pertanyaan }\end{array}$ & 26 & $86,67 \%$ \\
\hline $\begin{array}{l}\text { 10.Kemampuan menegaskan hal - hal penting/inti sari yang } \\
\text { berkaitan dengan pembelajaran }\end{array}$ & 24 & $80,00 \%$ \\
\hline $\begin{array}{l}\text { 11. Kemampuan menyampaikan judul sub materi } \\
\text { berikutnya/memberikan PR kepada siswa/menutup pelajaran }\end{array}$ & 25 & $83,33 \%$ \\
\hline 12.Kemampuan mengelola waktu & 24 & $80,00 \%$ \\
\hline 13.Antusias siswa & 24 & $80,00 \%$ \\
\hline 14.Antusias guru & 25 & $83,33 \%$ \\
\hline
\end{tabular}


Skor yang diperoleh dari masingmasing pengamat diubah dalam bentuk persen yaitu:

persentase skor rata - rata (SR)

$$
=\frac{\text { jumlah skor }}{\text { skor maksimal }} \times 100 \%
$$

maka dapat disimpulkan bahwa aktivitas dosen dalam melaksanakan proses pembelajaran menggunakan Problem based instruction pada siklus I berlangsung cukup.

\section{Refleksi}

Ditinjau dari segi pemahaman Konsep mahasiswa, masih ada mahasiswa yang tidak dapat menyelesaikan soal secara benar terkait dengan Pemahaman mahasiswa. Hal ini diketahui dari ragam pola jawaban siswa, yang dikelompokkan kedalam 3 (tiga) kategori yaitu:

a. Hasil jawaban benar dan mengikuti langkah-langkah;

b. Hasil jawaban salah dan tidak mengikuti langkah-langkah;

c. Jawaban kosong.

Dari hasil observasi aktivitas siswa terlihat belum dapat mencapai tujuan yang diharapkan. Observasi aktivitas siswa hanya mencapai persentase sebesar $70,56, \%$ dari seluruh aspek yang diamati. Dari setiap aspek yang diamati dan yang dinilai, masih banyak yang belum mencapai rata-rata $\geq$ $80 \%$.

Ini menunjukkan aktivitas siswa masih pasif dalam pembelajaran. Untuk itu pada siklus selanjutnya agar lebih ditingkatkan, agar kegiatan pembelajran tidak berkesan teacher centered. Jika aktivitas siswa meningkat, maka hasil belajar ataupun pemahaman konsep siswa mungkin akan meningkat juga. Dari hasil yang di dapat guru PTK, peneliti dan kolabolator berdikusi untuk mendapatkan solusi agar aktivitas siswa ini meningkat. Hasil diskusi akan dilaksanakan pada siklus selanjutnya.

Ditinjau dari hasil yang didapat, kemampuan guru dalam mengelola pembelajaran memperoleh kategori "baik". Dosen sudah mulai mampu dalam melaksanakan model pembelajaran problem based instruction, namun disini masih perlu perbaikan atau peningkatan pada aspek - aspek pengamatan karena masih ada aspek yaitu "kemampuan memimpin diskusi kelas/menguasai kelas" masih kurang terpenuhi dari kriteria yang diharapkan agar hasil yang diperoleh lebih baik dengan kriteria minimal "baik".

Tabel 3: Hasil Revisi Instrumen Tes Pemahaman Konsep Mahasiswa dan LKS

\begin{tabular}{llll}
\hline \multicolumn{1}{c}{ Yang direvisi } & \multicolumn{1}{c}{ Sebelum direvisi } & \multicolumn{1}{c}{ Sesudah direvisi } & \multicolumn{1}{c}{ Alasan direvisi } \\
\hline Instrumen tes & mahaiswa kurang & Bahasa dalam soal di & Sebagian dari \\
Pemahaman Konsep & memahami soal & sederhanakan agar & mahasiswa \\
mahasiswa No.4 dan & sehingga hasil dari & mahasiswa & kesulitan dalam \\
5 & jawaban mahasiswa & memahami soal & menjawab soal \\
& kurang memuaskan & tersebut & \\
LKS & $\begin{array}{l}\text { Bahasa dalam soal sulit } \\
\text { dipahami mahasiswa }\end{array}$ & $\begin{array}{l}\text { Bahasa dalam soal di } \\
\text { sederhanakan agar }\end{array}$ & $\begin{array}{l}\text { Sebagian dari } \\
\text { mhasiswa kurang }\end{array}$ \\
& $\begin{array}{l}\text { sehingga mahasiswa } \\
\text { tidak dapat menjawab }\end{array}$ & $\begin{array}{l}\text { mahasiswa } \\
\text { memahami soal }\end{array}$ & memahami soal \\
& soal dengan baik & tersebut & \\
\hline
\end{tabular}


PeTeKa (Jurnal Penelitian Tindakan Kelas dan Pengembangan Pembelajaran)

Vol 1 No 3 Tahun 2018 Hal 147-159

Untuk mewujudkan hal tersebut setelah pembelajaran selesai, dosen PTK, peneliti dan kolabolator berdiskusi untuk mencari solusi penyelesaian sehingga diharapkan adanya perubahan yang lebih baik pada siklus selanjutnya. Solusi yang didapat adalah, peneliti harus melaksanakan tindakan yang di berikan oleh guru senior dengan baik. Dan penyajian materi dan keterampilan menutup pembelajaran harus sesuai dengan RPP yang telah di buat peneliti, agar setiap kegiatan dapat dilaksanakan dengan baik.

Revisi instrumen tes dan perangkat pembelajaran yang di susun diatas untuk pertemuan 1 sampai 4 meningkatkan pemahaman konsep mahasiswa. Instrument tes yang disusun adalah tes pemahaman konsep siswa terdiri dari 5 butir soal yang masingmasing soal disusun berdasarkan indikator materi. Dosen dapat menyajikan materi dengan baik sesuai dengan harapan.

\section{Deskripsi Hasil Penelitian Tindakan Siklus II}

\section{Perencanaan}

Siklus II sama seperti siklus I, siklus yang terdiri dari 4 tahapan yaitu: perencanaan, pelaksanaan, observasi dan refleksi. Dilaksanakan pada hari senin, 22 juni 2018 - Senin 06 agustus 2018 di UGN Fakultas FKIP Padangsidimpuan. Bertolak dari pelaksanaan pada siklus I masih ada hal-hal yang belum dapat dicapai, dikarenakan dosen belum terbiasa dengan menerapkan model pembelajaran problem based instruction. Sama dengan siklus I di akhir pembelajaran Siklus II berlangsung, pada pertemuan ke 4 dilaksanakan tes pemahaman konsep mahasiswa, maka hasil yang didapat dari tes tersebut dapat dilihat pada tabel 4.

Berdasarkan tabel 4, dari 26 siswa diperoleh nilai rata - rata sebesar 72,26 dengan kriteria sebagai berikut : 4 orang siswa atau $15,39 \%$ dengan kategori "sangat baik", 3 orang siswa atau 11,53\% dengan kategori "baik", 16 orang siswa atau $61,53 \%$ dengan kategori "cukup", 2 orang siswa atau 7,69\% dengan kategori "kurang" dan 1 orang siswa atau 3,84\% dengan kategori "sangat kurang". Secara klasikal diperoleh kategori penilaian minimal "cukup baik" sebesar 84,62\% sedangkan kategori penilaian yang telah ditetapkan sudah terpenuhi yaitu $\geq 80 \%$ dari indikator kriteria yang ditetapkan. Berdasarkan hasil tersebut penelitian ini diberhentikan karena sudah memenuhi kategori yang diharapkan.

Tabel 4: Deskripsi hasil tes pemaman konsep analisa vektor siklus 2

\begin{tabular}{ccccc}
\hline No & Nilai & $\begin{array}{c}\text { Jumlah Siswa } \\
\text { (Orang) }\end{array}$ & Persentase & Kategori \\
\hline 1 & $90-100$ & 4 & $15,39 \%$ & Sangat Baik \\
2 & $80-89$ & 3 & $11,53 \%$ & Baik \\
3 & $65-79$ & 16 & $61,53 \%$ & Cukup \\
4 & $55-64$ & 2 & $7,69 \%$ & Kurang \\
5 & $0-54$ & 1 & $3,84 \%$ & Sangat Kurang \\
& Total & $\mathbf{2 6}$ & $\mathbf{1 0 0 \%}$ & \\
\hline
\end{tabular}




\section{Pengamatan}

Peneliti dan observer melaksanakan pengamatan terhadap proses pelaksanaan tindakan selama berlangsungnya siklus II. Pengamatan dibatasi pada pemahan konsep mata kuliah analisa vektor . selama proses tindakan peneliti, rekan sejawat, dan observer mengamati reaksi kelompok yang timbul ketika proses kegiatan belajar berlangsung. Pelaksanaan pembelajaran dilakukan sesuai tahapan pembelajaran problem based instruction .

Pembelajaran pada saat tindakan sangat berbeda dibanding pembelajaran sebelum tindakan kelas dilakukan. pada saat awal pembelajaran mahsiswa diseri tugas untuk mendefinisikan pengertian dari vektor dan bagaimana aplikasinya dalam kehidupan sehari-hari. mahaiswa harus dapat nenemukan masalah dalam dunia mereka yang akan diselesaikan dengan aljabar vektor. Kemudian mahasiswa yang sudah dibagi ke dalam beberapa kelompok memberikan satu atau lebih contoh-contoh objek yang mereka amati. setelah mahasiswa menemukan contoh objeknya, mereka harus menyebutkan alas an mereka memilih objek tersebut atau kajian tersebut untuk dimodelkan atau dianalisis secara vektor atau deferensiasi vektor. Kemudian membahas ciri-ciri atau karakteristik dari kajian tersebut untuk di modelkan menjadi analisis vektor.

Table 5: Hasil Observasi Siklus I Terhadap Kegiatan Dosen dan Siswa

\begin{tabular}{|c|c|c|}
\hline INDIKATOR & SKOR & $\begin{array}{l}\text { PERSENTASE } \\
\text { SKOR }\end{array}$ \\
\hline $\begin{array}{l}\text { 1. Kemampuan memotivasi siswa/mengkomunikasikan tujuan } \\
\text { pembelajaran }\end{array}$ & 28 & $93,33 \%$ \\
\hline $\begin{array}{l}\text { 2. Kemampuan menghubungkan pelajaran saat itu dengan } \\
\text { pelajaran sebelumnya atau membahas PR }\end{array}$ & 26 & $86,67 \%$ \\
\hline 3. Kemampuan menjawab soal & 25 & $83,33 \%$ \\
\hline $\begin{array}{l}\text { 4. Kemampuan mengarahkan siswa untuk menemukan } \\
\text { jawaban dan cara menjawab soal, dengan memberikan } \\
\text { bantuan terbatas }\end{array}$ & 22 & $73,33 \%$ \\
\hline $\begin{array}{l}\text { 5. Kemampuan mengoptimalkan interaksi siswa dalam } \\
\text { bekerja }\end{array}$ & 27 & $90,00 \%$ \\
\hline $\begin{array}{l}\text { 6. Kemampuan mendorong siswa untuk membandingkan } \\
\text { jawaban dengan jawaban temannya }\end{array}$ & 26 & $86,67 \%$ \\
\hline 7. Kemampuan memimpin diskusi kelas/ menguasai kelas & 26 & $86,67 \%$ \\
\hline $\begin{array}{l}\text { 8. Kemampuan mengarahkan siswa untuk menemukan sendiri } \\
\text { dan menarik kesimpulan tentang } \\
\text { konsep/prinsip/definisi/teorema/rumus/prosedur } \\
\text { matematika }\end{array}$ & 26 & $66,67 \%$ \\
\hline $\begin{array}{l}\text { 9. Kemampuan mendorong siswa untuk mau bertanya, } \\
\text { mengeluarkan pendapat atau menjawab pertanyaan }\end{array}$ & 27 & $90,00 \%$ \\
\hline $\begin{array}{l}\text { 10. Kemampuan menegaskan hal - hal penting/inti sari yang } \\
\text { berkaitan dengan pembelajaran }\end{array}$ & 28 & $93,33 \%$ \\
\hline $\begin{array}{l}\text { 11. Kemampuan menyampaikan judul sub materi } \\
\text { berikutnya/memberikan PR kepada siswa/menutup } \\
\text { pelajaran }\end{array}$ & 26 & $86,67 \%$ \\
\hline 12.Kemampuan mengelola waktu & 25 & $83,33 \%$ \\
\hline 13.Antusias siswa & 26 & $86,67 \%$ \\
\hline 14.Antusias guru & 26 & $86,67 \%$ \\
\hline
\end{tabular}


PeTeKa (Jurnal Penelitian Tindakan Kelas dan Pengembangan Pembelajaran)

Vol 1 No 3 Tahun 2018 Hal 147-159

Pelaksanaan pembelajaran di kelas perkuliahan diupayakan mengikuti langkah- langkah pembelajaran problem based instruction sebagaimana pada suklus I.

\section{Evaluasi Hasil}

Dari tabel 5 dapat dilihat hasil belajar siswa memperoleh kategori "baik". Dimana pada kategori "kurang" dan "sangat kurang" mengalami penurunan. Dari hasil diatas dapat diketaui bahwa hasil yang diperoleh sudah memenuhi kategori yang diharapkan dalam penelitian ini. Diharapkan Problem Based Instruction dapat diterapkan pada pembelajaran selanjutnya.

Hasil penelitian menunjukkan hasil tes pemahaman konsep siklus I dengan problem based instruction diperoleh persentase sebesar 69,23\% kriteria cukup dan pada silkus II diperoleh persentase sebesar 84,62\% kriteria baik. Untuk itu penelitian ini diberhentikan karena sudah memenuhi kategori yang diharapkan.

Dari tabel 5 kadar aktivitas mahasiswa siklus II diatas seperti Membaca dan memahami soal, Menulis (menyelesaikan/mempresentasekan, rangkuman/kesimpulan/hal-hal yang penting), Berdiskusi/bertanya kepada teman dan Berdiskusi/bertanya kepada dosen dapat dijelaskan persentase yang di dapat $86,67 \%$, hal ini menunjukkan hasil kadar aktivitas mahasiswa sudah sesuai dengan yang di harapkan dalam penelitian ini yaitu $\geq 80 \%$.

Berdasarkan uraian diatas, terlihat kadar aktivitas mahasiswa sudah terpenuhi sesuai dengan kriteria yang di harapkan. Mahasiswa sudah terbiasa dengan model pembelajaran problem based instruction. Dari hasil tersebut, penelitian ini diberhentikan karena sesuai dengan kriteria yang diharapkan dalam penelitian ini.

Refleksi

Ditinjau dari segi pemahaman konsep siswa, masih ada siswa tidak dapat menyelesaikan soal secara benar terkait dengan pemahaman siswa. Hal ini diketahui dari ragam pola jawaban siswa, yang dikelompokkan kedalam 3 (tiga) kategori yaitu :

1. Hasil jawaban benar mengikuti langkah-langkah;

2. Hasil jawaban salah tidak mengikuti langkah-langkah dan

3. Jawaban kosong.

Jika ditinjau dari segi aktivitas pada siklus II ini, aktivitas mahasiswa lebih baik dari siklus I. Hal ini terlihat dari hasil observasi aktivitas mahasiswa siklus II yang memperoleh kategori "baik" dengan persentase penilaian $86,68 \%$. Dilihat dari setiap aspek yang di nilai sudah terlihat peningkatkan yang signifikan, mulai dari "mendengarkan/ memperhatikan penjelasan guru/teman yang aktif" sampai dengan "perilaku siswa yang tidak relevan dalam kegiatan KBM". Mahasiswa semakin berantusias melakukan aktivitas dalam pembelajaran. Sehingga proses pembelajaran lebih aktif dari teacher centered to student centered.

Dari uraian di atas, penelitian diberhentikan pada siklus ini karena terlihat aktivitas siswa dalam pembelajaran sudah maksimal. Maka penelitian tidak dilanjutkan lagi karena hasil yang didapat sudah terpenuhi. Dari uraian di atas guru sudah mampu mengelola pembelajaran yang diterapkan, sehingga penelitian diberhentikan pada siklus II ini karena tujuan penelitian sudah tercapai. 


\section{Pembahasan}

Secara umum, pertanyaaan yang ingin diseleaikan dalam penelitia ini adalah :

1. Bagaimana Pemahaman Konsep mahasiswa terhadap pembelajaran mata kuliah analisis vektor dengan menggunakan model pembelajaran Problem Based Instruction ?

2. Bagaimanakah kadar aktivitas mahasiswa terhadap pembelajaran mataa kuliah analisis vektor dengan menggunakan model pembelajaran problem based instruction?

3. Bagaimanakah kemampuan dosen mengelola pembelajaran dengan menggunakan model pembelajaran Problem Based Instruction ?

Peningkatan pemahaman konsep matematika siswa dilihat berdasarkan hasil tes pemahaman konsep siswa pada siklus I terdapat 18 siswa yang memperoleh nilai minimal "cukup baik" dari 26 siswa yang mengikuti tes dengan persentase $69,23 \%$ dan hasil ini menunjukkan kalau tingkat pemahaman konsep siswa pada siklus I masih berada pada kategori cukup baik. Sedangkan pada siklus II terdapat 22 siswa yang memperoleh nilai minimal "cukup baik" dari 26 siswa yang mengikuti tes dengan persentase $84,62 \%$ dan hasil ini menunjukan kalau tingkat pemahaman konsep siswa pada siklus II telah berada pada kategori baik.

Hal ini menunjukkan terdapat kenaikan dari siklus I ke siklus II. Jadi dengan penerapan model pembelajaran problem based instruction dapat meningkatkan pemahaman konsep matematika mahasiswa pada mata kuliah analisis vektor.

Untuk hasil yang lebih jelas mengenai gambaran peningkatan pemahaman konsep siswa dari siklus I ke siklus II dapat dilihat dari gambar 1.
Hasil belajar

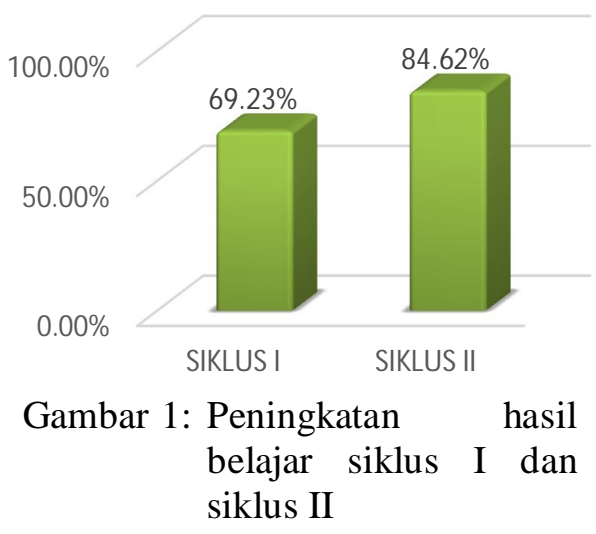

Bila ditinjau dari segi aktivitas siswa pada siklus I belum memenuhi kriteria yang diharapkan, dimana aktivitas siswa pada siklus I hanya memperoleh persentase sebesar 69,23\% dengan kategori 'cukup'. Sedangkan pada siklus II hasil yang diperoleh mengalami peningkatan dari siklus I, dimana diperoleh persentase sebesar $84,62 \%$ dengan kategori "baik". Hal ini menunjukkan terdapat kenaikan dari siklus I ke siklus II.

Aktivitas mahasiswa ini meningkat baik disebabkan kerjasama yang baik siswa dan guru atau siswa itu sendiri. Jadi didalam proses pembelajaran terjadi interaksi antara guru dan siswa atau siswa itu sendiri. Hal ini mengakibatkan suasana kelas menjadi kondusif, dimana masingmasing siswa dapat melibatkan kemampuannya semaksimal mungkin. Aktivitas yang timbul dari siswa akan mengakibatkan pula terbentuknya pengetahuan dan keterampilan yang akan mengarah pada peningkatan prestasi. Untuk hasil yang lebih jelas mengenai gambaran peningkatan aktivitas siswa dari siklus I ke siklus II dapat dilihat dari gambar 2 . 


\section{Aktivitas Siswa}

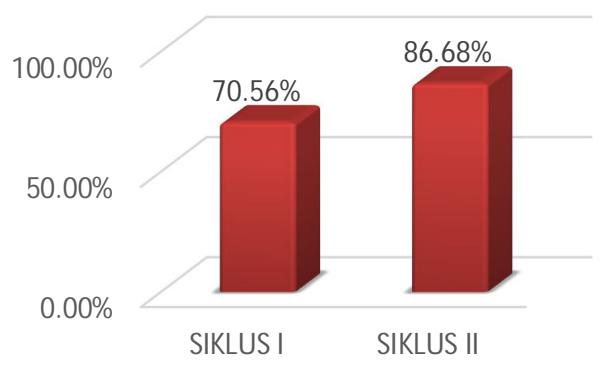

Gambar 2: Peningkatan aktivitas siswa

Hasil observasi aktivitas guru yang dilakukan menunjukkan bahwa pelaksanaan dengan model pembelajaran problem based instruction dalam penelitian ini berjalan dengan baik dan mengalami peningkatan selama pelaksanaan pembelajaran dengan model pembelajaran problem based instruction. Dengan demikian model pembelajaran problem based instruction dapat dipertimbangkan untuk meningkatkan mutu pembelajaran.

Berdasarkan hasil observasi kemampuan guru mengelola pembelajaran, pada siklus I dengan nilai rata - rata 3,4286 berada pada kategori "baik" dan juga pada setiap aspek pengamatan mendapat nilai "baik". Namun masih ada satu aspek yaitu kemampuan memimpin diskusi kelas/menguasai kelas mendapat nilai "kurang" Hal ini dapat dilihat dari pengamatan observer dari siklus I. Pada siklus II dengan nilai rata - rata 4,1071 dapat disimpulkan dari hasil penelitian, kemampuan guru memimpin diskusi kelas dan menguasai kelas sudah baik atau guru telah mampu menerapkan metode pembelajaran tersebut sehingga dapat meningkatkan pemahaman konsep matematika siswa.

Berdasarkan hasil dan pembahsan penelitian, maka penelitian ini ditemukan hal-hal sebagai berikut:

a. Ditinjau dari tingkat pemahaman konsep matematika siswa, setelah pemberian tindakan pada siklus I sebanyak 4 kali pertemuan, siswa diberikan tes pada pertemuan ke 5, diperoleh sebanyak 18 siswa siswa yang memperoleh nilai minimal cukup dari 26 siswa yang mengikuti tes dengan persentase $69,23 \%$ namun masih kurang dari $80 \%$, ini dikarenakan siswa belum terbiasa dengan model pembelajaran yang diberikan. Hal ini disebabkan : 1) siswa belum melakukan kegiatan pembelajaran dengan baik disebabkan pengajaran yang dilakukan belum maksimal, 2) siswa masih kurang berani dalam hal mengajukan pertanyaan/ menjawab pertanyaan, 3) masih ada siswa kurang aktif dalam belajar, 4) siswa kurang teliti dalam melakukan perhitungan. Kemudian setelah diberikan tindakan pada siklus II dengan 4 kali pertemuan, siswa diberikan tes pada pertemuan ke 5, hasil tes belajar diperoleh meningkat menjadi 21 siswa yang memperoleh nilai minimal cukup dari 26 siswa yang mengikuti tes dengan persentase $84,62 \%$ pada kategori "baik". Hal ini berarti ada peningkatan dari siklus I ke siklus II.

b. Bila ditinjau dari segi aktivitas siswa, selama tindakan diberikan pada siklus I diperoleh kadar aktivitas siswa sebesar 70,56\% sehingga belum memenuhi kategori yang ditentukan. Hal ini disebabkan belum maksimalnya siswa melakukan aktivitas sebagaimana apa yang di berikan pada aspek pengamatan. Kemudian selama tindakan pada siklus II diberikan, diperoleh kadar aktivitas siswa sebesar $86,68 \%$ hal ini menunjukkan bahwa kategori yang diharapkan telah tercapai $\geq 80 \%$. Hal ini berarti adanya peningkatan pada siklus I ke siklus II. 
Lilis Harianti Hasibuan, dkk. Upaya Meningkatkan Pemahaman Konsep ...

c. Hasil pengamatan kemampuan guru mengelola pembelajaran selama diberikan tindakan pada siklus I diperoleh kemampuan guru mengelola pembelajaran termasuk pada kategori "baik" dengan rata-rata penilain 3,4286, hal ini masih kurang dari kategori yang diinginkan disebabkan guru kurang dalam aspek kemampuan memimpin diskusi kelas/menguasai kelas. Selanjutnya pada siklus II terjadi peningkatan menjadi kategori "baik" dengan ratarata penilaian 4,1071. Hasil pengamatan ini sesuai dengan yang diharapkan dalam penelitian.

\section{SIMPULAN}

\author{
Penerapan Model problem based \\ instruction dapat meningkatkan \\ pemahaman konsep matematika \\ mahasiswa. Setelah dilaksanakannya \\ tindakan dapat dilihat dari hasil tes \\ pemahaman konsep siswa pada siklus I \\ terdapat 18 orang siswa dari 26 siswa \\ dengan persentase penilaian $69,23 \%$ dan \\ pada siklus II terdapat 22 siswa dari 26 \\ siswa dengan persentase penilaian \\ $84,62 \%$, hal ini menunjukkan bahwa \\ terdapat peningkatan sebesar $15,39 \%$ \\ dari Siklus I ke Siklus II. Hasil yang \\ didapat pada siklus II menunjukkan \\ bahwa sudah dapat terpenuhi kategori \\ yang diharapkan yaitu $\geq 80 \%$. Aktivitas \\ siswa di kelas VIII-5 meningkat dengan
}

penggunaan model pembelajaran problem based instruction. Hal ini dapat dilihat dari hasil observasi aktivitas siswa siklus I $70,56 \%$ dan siklus II $86,68 \%$, hal ini menunjukkan bahwa terdapat peningkatan sebesar $16,12 \%$ dari Siklus I ke Siklus II. Hasil yang diperoleh telah terpenui yaitu $\geq 80 \%$.

Kemampuan dosen meningkat dengan penggunaan model pembelajaran problem based instruction pada mata kuliah analisa vektor Untuk kemampuan guru pada siklus I diperoleh nilai rata rata sebesar 3,4286 dan pada siklus II diperoleh nilai rata - rata sebesar 4,10.

\section{DAFTAR PUSTAKA}

Arends, R. I. 2008. Learning to Teach: Belajar Untuk Mengajar Edisi Ketujuh Buku Dua. Yogyakarta : Pustaka Pelajar.

Bilgin. 2009. Problem Based Learning (Pembelajaran Berdasarkan Masalah). Yogyakarta : Pustaka Pelajar.

Kolmos, A. 2003. Problem Based Learning. Journal Of Problem Based Learning and project oriented learning.

Rusman. 2010. Model - Model Pembelajaran. Bandung : Rajawali Pers.

Trianto. 2007. Model-model Pembelajaran Inovatif. Jakarta: Grasindo. 